488

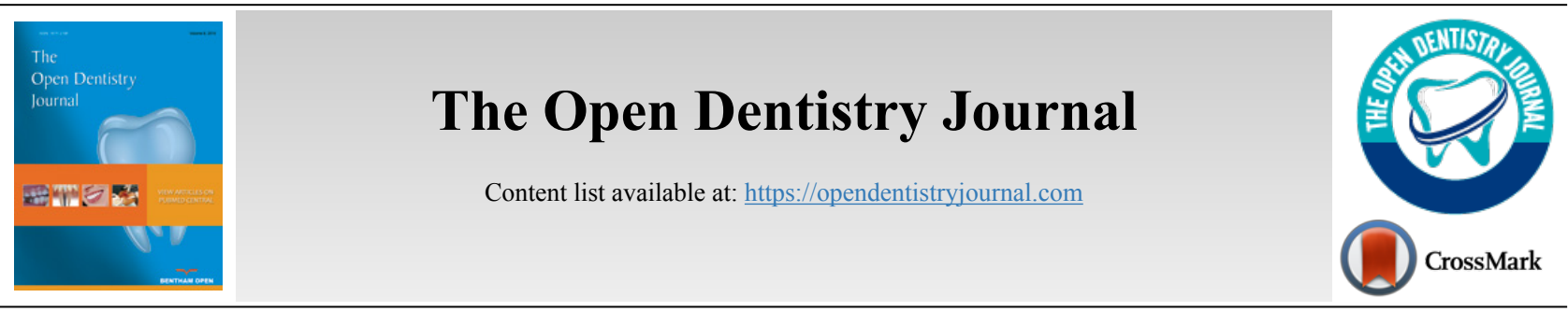

RESEARCH ARTICLE

\title{
In vitro Comparison of Apically Extruded Debris during Root Canal Retreatment with Rotary and Reciprocating Systems
}

María J. Burbano Balseca ${ }^{1}$, Silvana B. Terán Ayala ${ }^{2}$, Fábio D. da Costa Aznar ${ }^{3}$, Adriana R. de Freitas-Aznar ${ }^{4}$, Guillermo M. Aguirre Balseca ${ }^{1}$ and Karina M. S. Freitas,

${ }^{1}$ Department of Endodontics, Universidad de Los Hemisferios, Quito, Ecuador

${ }^{2}$ Department of Endodontics, Universidad Central del Ecuador, Quito, Ecuador

${ }^{3}$ Department of Endodontics, FACOP, Bauru, SP, Brazil

${ }^{4}$ Department of Pediatric Dentistry, Orthodontics and Public Health, University of São Paulo, Bauru, SP, Brazil

${ }^{5}$ Department of Orthodontics, Uninga University Center, Maringa, PR, Brazil

\section{Abstract:}

Introduction:

The extrusion of apical detritus during the retracting procedure is very important, as, besides eliminating materials of radicular obturation, aggressive agents and products such as the remains of dentin taken out, and microorganisms are generally located in tissue around the roots, producing undesired effects, such as inflammation, acute pain, post-operatory pain and delays in the periapical treatment.

Objective:

To determine the amount of apically extruded detritus using rotary and reciprocating retreatment systems.

\section{Methodology:}

An experimental comparative study as conducted in which 40 single-rooted human first premolars were analyzed. The instruments used were ProTaper Universal files up to F3 and sodium hypochlorite, and the sealing was made through the hybrid technique Tager. They were then kept at $37^{\circ} \mathrm{C}$ and $100 \%$ of humidity for 15 days so that the sealing material would seal. For the retracting procedure, experimental tubes previously weighted were used. The sample was divided randomly into two groups of 20 pieces. Group A: ProTaper R, and group B: Reciproc. Then, the irrigating material (distilled water) was evaporated from the tubes for 12 hours in a stove at $105^{\circ} \mathrm{C}$, and the experimental tubes were weighted in an analytical precision weighing scale $10^{-5} \mathrm{~g}$. The data was analyzed through the T Student with a significance level of $5 \%$.

Results:

Results indicated that groups A and B, retreatment with rotational ProTaper R and reciprocating retreatment system (Reciproc) showed a similar difference of initial and final weights, indicating similar apical extrusion of detritus.

Conclusion:

Both systems extruded a similar amount of detritus during the retreatment procedures.

Keywords: Apical extrusion, Endodontic retracting procedure, Rotating system, Reciprocating system, Root canal, Humidity.

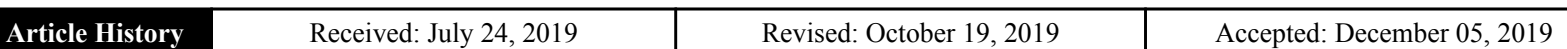

\section{INTRODUCTION}

During instrumentation of the root canal,it is inevitable that detritus which contains dentin, extrudes through the apical foramen, at the time of duct disobturation in performing a re-

* Address correspondence to this author at the Department of Orthodontics, UNINGÁ University Center, Rod PR 317, 6114, Maringá-PR-Brazil-87035-510; Tel: 5514991026446 ; E-mail:kmsf@uol.com.br treatment. In addition to the aforementioned aggressive agents, remaining of the gutta-percha, contaminated cement and important bacterial load are extruded to the periapical area [1, 2]. This can cause an immune response that can cause various side effects such as inflammation, exacerbation, post-operative pain, and delayed restoration of the periapical area [3].

Today, there are several advances in the endodontics in 
terms of instrumentation techniques and metallurgy systems that have led to the introduction of several files with innovative and safe designs. However, all shaping or retreatment techniques and instruments available on the market are still somehow related to a degree of debris extrusion, which is of concern $[2,4$ - 6].

Some techniques are known to extrude more debris than others, and the design of the instrument has an important influence, with different conicities, cross-section, cutting angle, groove depth, radial surfaces, cutting direction, thermomechanical treatment, movement, torque and speed with which they are used, and the number of instruments involved in the system. There are several factors involved, however, the results of these studies are very controversial as it cannot be determined with certainty what is the main factor for extruding a larger amount of debris apically, or if it is the combination of many of them [7].

What is determined is that apical crown techniques, properly maintaining working time and profused irrigation of the root canal system, are fundamental factors to reduce the amount of extruded debris in the periapical region [8].

There are several techniques and instruments for performing endodontic retreatments. However, rotary and reciprocating file systems today are preferred because of their multiple advantages [9].

It is vitally important to know that either a rotating or reciprocating system expels a larger amount of debris apically, since existing studies are contradictory and controversial, and most retreatment studies focus more on the quality of clearance and the time taken to use the files [10 - 12], so there is little information about how much debris these systems expel into the apical region.

This in vitro study aimed to compare the amount of extruded detritus through the apical foramen during the execution of retreatment using a rotational system (ProTaper Universal Retreatment Dentsply Sirona) and a reciprocating system (Reciproc VDW).

\section{MATERIALS AND METHODS}

This in vitro comparative study used human premolars donated by the UDICIS University.

Selection criteria included: Extracted single-rooted first human premolars whose lengths were not less than $20 \mathrm{~mm}$ and greater than $22 \mathrm{~mm}$, with completed root formation. Teeth with endodontic treatment or anterior duct manipulation with caries, resorption and root fractures were excluded.

Forty teeth were randomly divided into two groups of 20 teeth each. The samples were divided into two groups according to group A: ProTaper retreatment, Group B: Reciproc.

Soft tissue remnants and calculus on the external root surface were mechanically removed. The instrumentation was performed using the ProTaper Universal System. Initially, cervical and middle third was prepared by using the instruments SX, S1, and S2. Subsequently, F1, F2, F3 files were used sequentially at working length, with the files discarded every 5 teeth.
During the instrumentation, $1 \mathrm{ml}$ of $5.25 \%$ sodium hypochlorite was irrigated between each instrument with a syringe. The dentin layer was removed with $3 \mathrm{ml}$ of $17 \%$ EDTA for 3 minutes, and the ducts were again irrigated with $1 \mathrm{ml}$ of $5.25 \% \mathrm{NaOCl}$, followed by ultrasonic activation for one minute after each irrigator.

Root canals were dried out with paper points 30 and filled with standardized gutta-percha cones 30 and lateral condensation with Sealapex cement and accessories B. $6 \mathrm{~mm}$ from the working length of the cervical and medium surfaces were connected with the aid of one McSpadden Condenser \# 45 and access cavities sold with Cavit. Radiographs were taken in buccolingual direction to confirm the quality of obturation. All the samples were kept in glass vials with water at $37^{\circ} \mathrm{C}$ and toasted at $100 \%$ humidity in a BIOBASE incubator for 15 days to allow complete adjustment of the seller.

The experiment was based on the study by Myers and Montgomery [13] (Fig. 1). For the study, 40 Eppendorf tubes labeled with the corresponding one were used, the cap of each one removed, and weighed 3 times on an analytical balance with a precision of $10^{-5} \mathrm{~g}$ to obtain the average value and establish the initial weight of each tube.
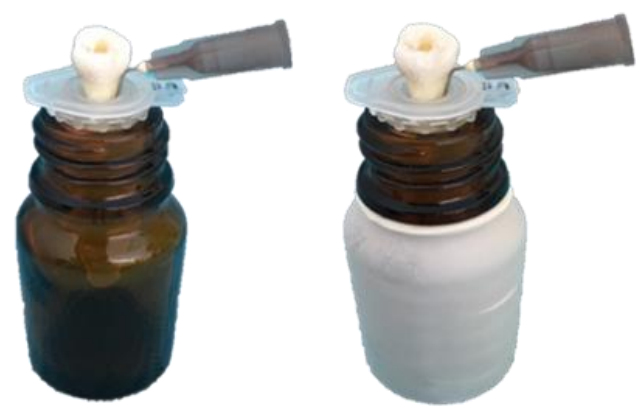

(Fig. 1). Modified model of Myers and Montgomery [13].

Afterwards, at the end of each tube, a perforation in the center with a hot instrument was performed (Gutapercha Condenser \# 30). Each labeled tooth was subjected to pressure. Additionally a $27 \mathrm{G}$ needle was placed through the cover with the object of balancing the internal and external air pressure, allowing the extrusion of the detritus. Subsequently, the cover with the tooth and the needle were placed in the Eppendorf labeled tube. Additionally, the armed tubes were placed inside glass vials to stabilize them and make it impossible to contact the tubes during the experiment. In addition, they were covered with latex to blind the operator regarding waste production during root canal retreatment.

For retreatment with different techniques, the sample was divided into 2 groups with 20 samples each. The groups represented the 2 retreatment systems, rotational and reciprocating, that is, ProTaper R and Reciproc. For this procedure, no type of solvent was used. The irrigator used for retreatment was distilled water and $20 \mathrm{ml}$ per tooth, to avoid any possible weight gain caused by the formation of $\mathrm{NaOCl}$ crystals [9]. For the final irrigation protocol, $17 \%$ EDTA was used for three minutes and ultrasonic activation for 1 minute. The engine used 
to activate the files was X Smart Plus. The files were discarded every five teeth.

\subsection{GROUP A: ProTaper Retreatment System}

Twenty teeth were prepared with ProTaper retreatment instruments (Dentsply Maillefer, Ballaigues, Switzerland), as indicated by the technique of this system. The D1 file was used to eliminate the obturation of the coronal third, while D2 was used for the middle third and D3 at work length. The file was cleaned, and the conduct was irrigated after each movement. The apical preparation was performed with ProTaper Universal F2, F3, and F4 files at $300 \mathrm{rpm}$ and $3 \mathrm{Ncm}$ torque. For better cleaning of the apical third, it was finished with a file with a diameter of 40 .

\subsection{GROUP B: Reciproc System}

Twenty teeth were deobturated with Reciproc (VDW, Munich, Germany) as indicated by the technique of this system. The filling of the duct entry was removed with a Gate 3 at $100 \mathrm{rpm}$. Then the pecking movement of an amplitude of 3 $\mathrm{mm}$ was performed, with R25 file. After three completed pecking movements, a slight apical pressure was changed to a brushing movement against the walls of the duct and so on, until reaching the working length. The file was cleaned, and the conduct was irrigated after each movement. The apical preparation was done with an R40 file. The files were used at $300 \mathrm{rpm}$ and $4.1 \mathrm{Ncm}$. The better cleaning of the apical third was finished with a file with a diameter of 40 .

Once the retreatment was finished, the caps with the tooth and the needle were removed. The root was washed with $1 \mathrm{ml}$ of distilled water in the tube to collect the debris that adhered to the root surface. Each tube was then stored in an oven at $105^{\circ} \mathrm{C}$ for $12 \mathrm{~h}$ to evaporate the distilled water before weighing the dry residues. Subsequently, the Eppendorf tubes with detritus were weighed on the analytical balance (precision $10^{-5}$ ), for three times to calculate the average value.

The weighing protocol was the same for both the empty tubes and detritus tubes. The glass vial was placed on the scale with the reading bought to zero. The Eppendorf tube was placed inside the vial, the weight was recorded three times and the average value was obtained. The net weight of the extruded detritus was determined by subtracting the initial weight from the final weight of the tubes obtained in grams and transformed to milligrams.

\subsection{Statistical Analysis}

Based on a previous study [2], a sample size calculation was performed (Alpha of $5 \%$, beta of $20 \%$, power of the test $80 \%$ ) and indicated that the sample size for each group must be of at least 18 teeth.

Shapiro-Wilk test was used to check the normality of data. Since data presented a normal distribution, a parametric test was used. The independent $t$ test was used to compare the weights between the groups.

The statistical analysis was performed with Statistica software (Statistica dor Windows version 7.0, Statsoft, Tulsa, Okla, USA), and the results were considered significant for
$P<0.05$.

\section{RESULTS}

Table 1 shows the comparison of the difference between the initial and final weights, indicating the amount of detritus that both systems extruded apically during the retreatment. ProTaper R showed a mean detritus extrusion of $0,4985 \mathrm{mg}$ and the Reciproc showed a mean apical debris extrusion of $0,4673 \mathrm{mg}$ (Table 1).

Table 1. Intergroup comparison of the weights (Independent t-test).

\begin{tabular}{|c|c|c|c|c|c|c|c|}
\hline \multirow{2}{*}{ Variable } & \multicolumn{2}{|c|}{$\begin{array}{c}\text { Group A } \\
\text { ProTaper R } \\
\text { N=20 }\end{array}$} & $\begin{array}{c}\text { Group B } \\
\text { Reciproc } \\
\text { N=20 }\end{array}$ & \multicolumn{2}{|c|}{$\begin{array}{c}\text { Difference } \\
\text { among Groups } \\
\text { A and B }\end{array}$} & \multirow{2}{*}{$\boldsymbol{P}$} \\
\cline { 2 - 6 } & Mean & S.D. & Mean & S.D. & Mean & S.D. & \\
\hline $\begin{array}{c}\text { Difference } \\
\text { of Initial } \\
\text { and Final } \\
\text { Weights } \\
\text { (mg) }\end{array}$ & 0.4985 & 0.3796 & 0.4673 & 0.4382 & 0.0312 & 0.0585 & 0.4054 \\
\hline
\end{tabular}

Results indicated that both rotational and reciprocating retreatment systems extruded a similar amount of apical detritus (Table 1).

\section{DISCUSSION}

The effectiveness, cleanliness and safety of the rotary nickel-titanium (NiTi) system ProTaperR have already been proved [12, 14 - 16]. Regarding Reciproc, there is increasing scientific evidence of the safety and effectiveness of this system $[12,15,16]$. However, regarding the amount of apical extrusion of detritus, the results of the studies are controversial, and most retreatment studies focus more on the quality of clearance and the time taken to use the files [10 - 12]. This way, this study compared the amount of extruded detritus during retreatment with ProTaperR and Reciproc systems.

The results of the present study showed that apical debris extrusion occurred regardless of the type of retreatment system used. This is similar to the results obtained by previous studies reporting that all the file systems used for root canal preparation, operated both in continuous rotation and reciprocation and also including hand instrumentation, can cause different degrees of apically extruded debris [2, 6, 17 - 19].

Besides, the results showed a similar amount of apical detritus extrusion in both retreatment systems used (Table 1); i.e., the ProTaper R and Reciproc groups showed almost the same weight difference, indicating the same apical debris extrusion after endodontic retreatment.

Silva et al. [2], quantitatively studied the amount of apically extruded detritus comparing 1 rotary system and 2 reciprocating systems during endodontic retreatment, demonstrating that ProTaper retreatment showed greater extrusion $(0.380 \mathrm{mg})$ compared to Reciproc $(0.188 \mathrm{mg})$, with an average difference of $0.20 \mathrm{mg}$, proving that the ProTaper Universal Retreatment system produced significantly more debris than both reciprocating systems.

In our study, despite without a statistically significant 
difference, the ProTaper $\mathrm{R}$ also numerically showed a greater amount of apical detritus extrusion of $0,4985 \mathrm{mg}$ compared to $0,4673 \mathrm{mg}$ of the apical debris extrusion of Reciproc. A possible reason for the difference in the statistical results between the two studies is due to the distilled water used in the present study and Silva et al. [2], used sodium hypochlorite as irrigating fluid, which would increase the final weight due to the formation of $\mathrm{NaOCl}$ crystals [9], which precipitated at the time of drying the samples in the oven.

The greater extrusion of detritus produced by the ProTaper Universal rotary retreatment system may be due to the number of files used during the procedure. In addition, during the application of the technique, ProTaper Universal F2, F3, and F4 files were used to finish the treatment, unlike Reciproc, where two non-active tip files R25 were used for retreatment and R40 file for final instrumentation. As expressed by Bramante et al., [20] to achieve an improved cleaning, reinstrumentation is required up to the working length, using instruments larger than those used during the initial retreatment [21].

Y1lmaz and Ozyurek [19] compared the amount of apically extruded residue during the retreatment procedures with ProTaper Next (PTN), Reciproc (RPC) and Twisted File Adaptive (TFA). The results showed that the amount of detritus that Reciproc extruded was significantly greater in contrast to the rotary systems (residues material of Reciproc $>$ Twisted file adaptive $>$ ProTaper Next, respectively). These results do not agree with the findings of the present study. One of the main reasons probably is because that these authors used ProTaper Next, usually used for instrumentation and not for retreatment. Instead, ProTaper Universal Retreatment was used in this investigation that has an active tip for such function.

Although studies of apical extrusion of detritus in endodontic instrumentation declare that reciprocating systems extrude a greater amount of detritus than rotary systems [5, 6], in retreatment, an opposite trend can be observed since the instruments designed specifically for retreatment are rotary and their initial file has an active tip that allows them to penetrate more easily into the filling material, unlike reciprocating instrumentation systems [22].

Clinical relevance of the present study is that it helps the endodontist in choosing the best system for desobturation in cases of non-surgical endodontic retreatment, considering the amount of apical extrusion of detritus. Since both systems evaluated in the study presented similar results, other characteristics must be considered when choosing the desobturation system to be used in each case.

\section{CONCLUSION}

The ProTaper $\mathrm{R}$ rotational retreatment system and the Reciproc reciprocating system showed a similar amount of apical extrusion of detritus during the retreatment procedures.

\section{ETHICAL APPROVAL AND CONSENT TO PARTICIPATE}

Not applicable.

\section{HUMAN AND ANIMAL RIGHTS}

No animals/humans were used for studies that are the basis of this research.

\section{CONSENT FOR PUBLICATION}

Not applicable.

\section{AVAILABILITY OF DATA AND MATERIALS}

The datasets analyzed during the current study are available from the corresponding author upon request.

\section{FUNDING}

None.

\section{CONFLICT OF INTEREST}

The authors declare no conflict of interest, financial or otherwise.

\section{ACKNOWLEDGEMENTS}

Declared none.

\section{REFERENCES}

[1] Siqueira JF Jr. Microbial causes of endodontic flare-ups. Int Endod J 2003; 36(7): 453-63.

[http://dx.doi.org/10.1046/j.1365-2591.2003.00671.x] [PMID: 12823700]

[2] Silva EJ, Sá L, Belladonna FG, et al. Reciprocating versus rotary systems for root filling removal: assessment of the apically extruded material. J Endod 2014; 40(12): 2077-80.

[http://dx.doi.org/10.1016/j.joen.2014.09.009] [PMID: 25442728]

[3] Topçuoğlu HS, Aktı A, Tuncay Ö, Dinçer AN, Düzgün S, Topçuoğlu G. Evaluation of debris extruded apically during the removal of root canal filling material using ProTaper, D-RaCe, and R-Endo rotary nickel-titanium retreatment instruments and hand files. J Endod 2014; 40(12): 2066-9.

[http://dx.doi.org/10.1016/j.joen.2014.09.004] [PMID: 25443282]

[4] De-Deus GA, Nogueira Leal Silva EJ, Moreira EJ, de Almeida Neves A, Belladonna FG, Tameirão M. Assessment of apically extruded debris produced by the self-adjusting file system. J Endod 2014; 40(4): 526-9.

[http://dx.doi.org/10.1016/j.joen.2013.07.031] [PMID: 24666904]

[5] Ahn SY, Kim HC, Kim E. Kinematic Effects of nickel-titanium instruments with reciprocating or continuous rotation motion: A systematic review of in vitro studies. J Endod 2016; 42(7): 1009-17. [http://dx.doi.org/10.1016/j.joen.2016.04.002] [PMID: 27185740]

[6] Bürklein S, Schäfer E. Apically extruded debris with reciprocating single-file and full-sequence rotary instrumentation systems. J Endod 2012; 38(6): 850-2.

[http://dx.doi.org/10.1016/j.joen.2012.02.017] [PMID: 22595125]

[7] Kirchhoff AL, Fariniuk LF, Mello I. Apical extrusion of debris in flatoval root canals after using different instrumentation systems. J Endod 2015; 41(2): 237-41.

[http://dx.doi.org/10.1016/j.joen.2014.09.023] [PMID: 25447504]

[8] Tanalp J, Güngör T. Apical extrusion of debris: A literature review of an inherent occurrence during root canal treatment. Int Endod J 2014; 47(3): 211-21.

[http://dx.doi.org/10.1111/iej.12137] [PMID: 23711187]

[9] Huang X, Ling J, Wei X, Gu L. Quantitative evaluation of debris extruded apically by using ProTaper Universal Tulsa rotary system in endodontic retreatment. J Endod 2007; 33(9): 1102-5.

[http://dx.doi.org/10.1016/j.joen.2007.05.019] [PMID: 17931943]

[10] Martins MP, Duarte MA, Cavenago BC, Kato AS, da Silveira Bueno CE. Effectiveness of the ProTaper next and reciproc systems in removing root canal filling material with sonic or ultrasonic irrigation: A micro-computed tomographic study. J Endod 2017; 43(3): 467-71. [http://dx.doi.org/10.1016/j.joen.2016.10.040] [PMID: 28131411]

[11] Nevares G, de Albuquerque DS, Freire LG, et al. Efficacy of ProTaper NEXT compared with reciproc in removing obturation material from 
severely curved root canals: A micro-computed tomography study. J Endod 2016; 42(5): 803-8.

[http://dx.doi.org/10.1016/j.joen.2016.02.010] [PMID: 27117757]

[12] Silva EJ, Orlowsky NB, Herrera DR, Machado R, Krebs RL, Coutinho-Filho TdeS. Effectiveness of rotatory and reciprocating movements in root canal filling material removal. Braz Oral Res 2015; 29: 1-6.

[PMID: 25466331]

[13] Myers GL, Montgomery S. A comparison of weights of debris extruded apically by conventional filing and Canal Master techniques. J Endod 1991; 17(6): 275-9.

[http://dx.doi.org/10.1016/S0099-2399(06)81866-2] [PMID: 1940753]

[14] Somma F, Cammarota G, Plotino G, Grande NM, Pameijer CH. The effectiveness of manual and mechanical instrumentation for the retreatment of three different root canal filling materials. J Endod 2008; 34(4): 466-9.

[http://dx.doi.org/10.1016/j.joen.2008.02.008] [PMID: 18358899]

[15] Zuolo AS, Mello JE Jr, Cunha RS, Zuolo ML, Bueno CE. Efficacy of reciprocating and rotary techniques for removing filling material during root canal retreatment. Int Endod J 2013; 46(10): 947-53. [http://dx.doi.org/10.1111/iej.12085] [PMID: 23506150]

[16] Rios MdeA, Villela AM, Cunha RS, et al. Efficacy of 2 reciprocating systems compared with a rotary retreatment system for gutta-percha removal. J Endod 2014; 40(4): 543-6.

[http://dx.doi.org/10.1016/j.joen.2013.11.013] [PMID: 24666908]
[17] Üstün Y, Çanakçi BC, Dinçer AN, Er O, Düzgün S. Evaluation of apically extruded debris associated with several $\mathrm{Ni}$-Ti systems. Int Endod J 2015; 48(7): 701-4.

[http://dx.doi.org/10.1111/iej.12369] [PMID: 25112960]

[18] Uslu G, Özyürek T, Yılmaz K, Gündoğar M, Plotino G. Apically extruded debris during root canal instrumentation with reciproc blue, hyflex edm, and xp-endo shaper nickel-titanium files. J Endod 2018; 44(5): 856-9.

[http://dx.doi.org/10.1016/j.joen.2018.01.018] [PMID: 29550013]

[19] Yilmaz K, Özyürek T. Apically extruded debris after retreatment procedure with reciproc, ProTaper next, and twisted file adaptive instruments. J Endod 2017; 43(4): 648-51.

[http://dx.doi.org/10.1016/j.joen.2016.12.003] [PMID: 28258810]

[20] Bramante CM, Fidelis NS, Assumpção TS, et al. Heat release, time required, and cleaning ability of MTwo R and ProTaper universal retreatment systems in the removal of filling material. J Endod 2010; 36(11): 1870-3.

[http://dx.doi.org/10.1016/j.joen.2010.08.013] [PMID: 20951303]

[21] Medeiros JBA, Gabardo MCL, Moraes SH, Faria MIA. Evaluation of four gutta-percha removal techniques for endodontic retreatment. RSBO 2014; 11: 340-5.

[22] Giuliani V, Cocchetti R, Pagavino G. Efficacy of ProTaper universal retreatment files in removing filling materials during root canal retreatment. J Endod 2008; 34(11): 1381-4. [http://dx.doi.org/10.1016/j.joen.2008.08.002] [PMID: 18928852]

\section{(C) 2019 Balseca et al.}

This is an open access article distributed under the terms of the Creative Commons Attribution 4.0 International Public License (CC-BY 4.0), a copy of which is available at: (https://creativecommons.org/licenses/by/4.0/legalcode). This license permits unrestricted use, distribution, and reproduction in any medium, provided the original author and source are credited. 